IJBPAS, December, Special Issue, 2021, 10(12): 348-362

ISSN: 2277-4998

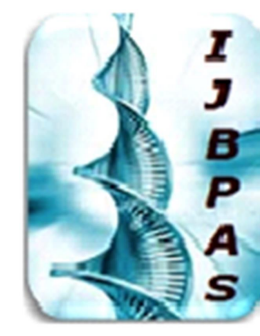

International Journal of Biology, Pharmacy and Allied Sciences (IJBPAS)

'A Bridge Betuen caboratory and QRendo'

Www.ibpas.com

\title{
INTERDEPENDENCE OF BIODIVERSITY AND INDIGENOUS PEOPLE: CASE STUDY OF SOLIGA TRIBE \& TIGERS
}

\section{SMITA PANDEY ${ }^{1^{*}}$, SUJATA ${ }^{2}$ ARYA AND URVI TEMBEY ${ }^{3}$}

1: Assistant Professor, Chotanagpur Law College, Ranchi

2: Assistant Professor, Symbiosis Law School, Pune, Symbiosis International (Deemed

$$
\text { University), Pune }
$$

3: Symbiosis Law School, Pune, Symbiosis International (Deemed University), Pune

*Corresponding Author: Smita Pandey: E Mail: smitapparashar@gmail.com

Received $19^{\text {th }}$ Aug. 2021; Revised 20 ${ }^{\text {th }}$ Sept. 2021; Accepted 29 $9^{\text {th }}$ Oct. 2021; Available online $1^{\text {st }}$ Dec. 2021

https://doi.org/10.31032/IJBPAS/2021/10.12.2033

\begin{abstract}
Indigenous knowledge is herein defined as a cumulative body of knowledge and beliefs handed down through generations by cultural transmission about the relationship of living beings, (including humans) with one another and with their environment (Berkes. F, 1993). The tribal population depend highly on the environmental resources for their sustenance. They are not skilled enough to use or import resources available outside the purview of environment. Thus, it is imperative that they take utmost care of natural resources and help it flourish (Gadgil, M. 1987).

Indigenous knowledge is of utmost importance for ecological balance in the industrialized world. This traditional knowledge is an asset if considered from point of view of saving our environment. They have acquired traditional knowledge from their ancestors, which they tend to lose if shifted from their traditional place of dwelling. For various reasons, they have been forced to migrate from their place of origin and sustenance. Then these indigenous people with time mingle with the organised societies. They get integrated in the general corridors of trade, economy, population, and the means of livelihood. This has further pushed these indigenous people away from their traditional way of living and the dove of knowledge gained out of it. When BRT Tiger Reserve was being built in Karnataka, Soliga Tribe were, piece by piece, forced to confine themselves in small pocket of the forest. Still with time,
\end{abstract}


they were able to prove that their presence in the forest had helped in the population growth of tigers in the same area. This paper takes up case study of Soliga Tribe and its role in tiger conservation in Karnataka. This paper focuses on the symbiotic relation that the Soliga tribe shares with nature leading to improved biodiversity zone of the area.

\section{Keywords: Indigenous knowledge, environmental, Tiger Reserve, biodiversity, Tribal INTRODUCTION}

Tribal communities and forests have shared a symbiotic relationship since time immemorial. Tribes have depended on forests to fulfil their basic needs, while the forest is considered sacred and protected by the tribal population. The tribal population believe that local deities reside in these groves, and it is therefore prohibited for them to fell trees or reduce forest cover. It is estimated that $90 \%$ of tribal communities in India live in or in close proximity to forests (Jadegowda, M. et al , 2008). As per the Forest Survey of India Report (2019), about $60 \%$ of forest cover and $63 \%$ of dense forests lie in 187 tribal districts. Standing testament to the intimate relationship between nature and humans is the indigenous Soliga tribe of the Biligiriranga Hills region situated in Chamarajanagar district of Southern Karnataka. $50 \%$ of the income of the Soligas is from the sustainable harvesting of minor forest produce (M. Jadegowda et $a l, 2008)$. The tribe, whose name stands for 'Children of Bamboo', have been integral in understanding the biodiversity of the region and play a pivotal role in conservation efforts as a result of their profound traditional knowledge.

\section{Problem Statement}

Biligiri Rangaswamy Temple (BRT) is situated in South-Eastern Karnataka, and is considered a Tiger reserve area. A study by an NGO (Survival International), working towards cause of tribal rights, has reported that the population of tigers has increased in recent times. This area has been earmarked by government for the tribal population to stay.

The primary reason for this is that the Soliga tribe worships tigers as Gods, and avoid hunting or conflict at all costs. Tribal communities have often been evicted from their natural environment under the garb of tiger conservation. In 2014, the tribal population belonging to Baiga tribe were evicted to make room for growing population of tigers and facilitate tourists in Kanha national Park. However, as evident from the example of the BRT Tiger reserve, tigers tend to do well and their population rises when the tribal communities remain. The tribal community often takes a hit, as the thousands of tourists 
who visit these tiger reserves bring in huge amounts of money. This has grave and far reaching consequences. The constant human presence in these reserves because of the tourists makes the tigers accustomed to human presence, which in turn helps the poachers get close to the tigers.

The eviction of indigenous people from their homeland is not a step towards biodiversity conservation, but an act that further disturbs the delicate balance between nature and tribal population. The traditional knowledge of the Soliga tribe and their presence in the reserve not only strengthens conservation efforts, but also serves as a model for promoting conservation efforts, while empowering the tribal communities.

\section{Objectives of the Research}

The main aims of the research are to understand the rituals followed by tribal population which help in preserving or destroying biodiversity. This basic aim is fulfilled with the specific study of Soliga tribe. The secondary aim of the research paper was to find out if the tribal population in India are given certain legal rights to preserve biodiversity. The research also aimed to enquire whether the presence of tribal in protected areas accelerate biodiversity conservation efforts.

\section{LITERATURE REVIEW}

Posey (Posey, D.A. 1985) has produced the evidence of use of tribal population in preserving the biodiversity in Amazon valley. Taylor (Taylor, K.I. 1988) has worked on Amazon forest's Ecuador. The paper reports about how Runa tribes work on agroforestry and through traditional knowledge helped it prosper. Hawaiian tribal population have since long worked on fish from pond and sea in consonance with agriculture and uplifted river valleys and forests (Costa-Pierce, B.A. 1987). Lewis' (Lewis, H.T. 1989) work in Australian tribes improved their food condition by applying knowledge of fire and its use.

\section{METHODOLOGY}

The study is a mix of doctrinal research and analysis of secondary empirical data regarding the plight of Soliga tribes in Karnataka. The doctrinal research has been used to evaluate the relevance or effectiveness of laws, concepts, legal institutions and governmental policies. This methodology is essentially a library based study. For the study, data was collected from both primary as well as secondary sources. The method used in such research involved the obtaining of information on a systematic basis and then examining and evaluating it in order to arrive at some conclusion.

\section{Biodiversity \& Indigenous People}

It is believed and proved various times that the tribal population with its traditional 
knowledge and know how can and have saved and helped in prospering of the biodiversity zones, not only in India but on a global level as well. Some of the national and international examples have been illustrated below:

Conservation of Biodiversity and Tribal: International Perspective

On International platform, there are enough examples that can be shared to put forth the importance of tribal population for conservation of biodiversity:

a. Brazil in Amazon valley, has forest area called Apte. The tribal population inhabiting that place is called Kayapo Indians (Irvine, D. 1989). They have put concerted effort to increase the population of variety of species in number and quantity to around $35 \%$.

b. In China certain tribes combine various carps to develop fodder for aquaculture. (Folke, C. et al., 1989). With the help of traditional knowledge of advantages of each carp they have developed this fodder (Johanne Fischer et al., 2013)

c. In Indonesia, Zhujiang delta, used waste from domestic farming for aquaculture systems (tambak) (Ruddle, K. and Zhong, G. 1988). The tambaks themselves were polyculture ponds, often combining fish, vegetables and tree crops (Costa-Pierce, B.A. 1988). d. Hawaiian tribal population have since long worked on fish from pond and sea in consonance with agriculture and uplifted river valleys and forests (Costa-Pierce, B.A. 1987).

e. Lewis' (Lewis, H.T. 1989) reported that Australian tribes improved their food condition by applying knowledge of fire and its use.

f. African tribes are well known and famous for using rotation crops. This enhances the fertility of soil as well as produce. (Niamir, M. 1990).

g. Sahel being a semiarid region, follows rainy season for growing crops. The tribes in this area adapt to the same condition (Sinclair, A. et al . 1985).

h. Feit (Feit, H.A. 1986) has reported on Waswanipi Cree Amerindian tribes of James Bay area. He says that they have hunted while following resting period for beaver. This has presented amazing result.

i. Berkes (Berkes, F. 1982) reported about Chisasibi Cree goose hunters. These tribals hunted rabbits on a 7-day rotation cycle.

Conservation of Biodiversity and Tribal: National Perspective

India is blessed with a rich biodiversity, which comprises of an abundance of unique flora and fauna. Some of the examples can be cited as below:

a) The tiger of Bengal is our national animal and pride of the nation. It is a 
representation of power, courage and the majestic nature of the country. The Bengal tiger is the key stone species of Indian forests and occurs in protected forests throughout the country. The tiger, which has always occupied the throne in East Asia was declared as the national animal of India in 1972. India launched the Project Tiger in 1973. With an aim to conserve the tiger population, India's experience in implementing various biodiversity governance models serves as a vantage point (Krishnan, P., et al., 2012). In an ever-commercializing world, the sustainable model found in the BRT Hills sets precedent for future government and tribal interaction (Malhotra, K. et al., 1989).

(a) Sacred groves rechristened as "safety forest", by citizens residing in Mizoram, in north-eastern India, and comprising majorly of tribes, is safeguarded as against the "supply forest" (Malhotra, K.C. 1990). It is considered one way of safeguarding biodiversity. (Joshi, N.V. and Gadgil, M. 1991).

(b) Ficus is found all over India but majorly concentrated in North Eastern part of the country. (Terborgh, J. 1986). Local people of the area have understood that Ficus is an important tree for the environment as it houses various kinds of birds and other primates including bays. This was a known fact for these tribal since ages and thus they have always concentrated on safeguarding the Ficus trees.

(c) Fruit bats are considered to be auspicious and dare thus not disturbed during day and are only hunted when foraging in South India. (Gadgil, M. and Guha, R. 1992).

Events like harvesting and crop production are considered as group activities by tribal leading to bonding and concerted effort by each one of the group. This in turn leads to higher production and sustained living of the community (Slobodkin, L.B. 1968).

\section{Issues of Tribal in India}

Due to migration of tribes from one state to another, a specific region for these tribal population is very hard to demarcate (Bcteille 1998:189; Hardinan 1987:15-16).

Taking certain examples:

- The tribal population residing today in Jharkhand, e.g., Oraons and Mundas, consider themselves original natives of Assam and Bengal. Although, this has not been accepted by the people of these two states but it still sparks a dialog.

- The tribal population of Assam, Bodos, Mishings and others, consider themselves to be tribal from Bihar, Orissa and Madhya Pradesh. Although this has been contested by the natives of these states. 
- Tribes in the north-eastern region have mass migrated long back to Andaman Islands. They have converted into farmers and cultivators by claiming land out of forests. With this, they are dispossessing the native Jarvas from their territories.

Mostly dominant species are given certain rights as denied to these minority tribes. Due to this, the minority tribes are devoid of their own rights over their land, property, resources, forests, minerals and other biodiversity resources. With time, this leads to misery which can be termed inhuman, unjust and a form of exploitation.

\section{Soliga Tribes and Tigers}

The Soliga Tribe, residing in Biligiri Rangaswamy Temple Hills of the Chamarajanagar district of Southern Karnataka maintain an intimate and close relationship with the forest. The BRT wildlife sanctuary area is spread over 540 sq kilometres and it is well known for the plethora of flora and fauna it houses. The Soliga Tribe in BRT Tiger Reserve, have accelerated tiger conservation efforts. It has been reported that there has been a noticeable increase in the tiger population of the Reserve since the tribal have been given the right to stay.

Social structure- The Soligas function on the basis of a clan structure. Their practices of forest conservation are linked to this clan system, under which, all the animals, which have been traditionally worshipped by the Soligas, belong to various clans in the social hierarchy.

Traditional Knowledge- It is believed that the tribal people only look for their community and destroy the forest by burning and unplanned farming. However, as per the traditional knowledge of tribes and their understanding of the terrain, it is argued that fire is used as a management tool. They believe that controlled ground fires helps in curbing invasive plant species, and regeneration of indigenous species. Moreover, it is also argued that controlled fires aid in regeneration and availability of food for local wildlife. There are therefore enough grazing areas available for the animals, which in turn is beneficial for the entire ecosystem. Scarcity of grazing areas in the forest results in animals changing their food habits and shifting to other areas. This in turn negatively affects the predators in that ecosystem. The presence of the Soliga tribe, and the activities practiced by them therefore helps in maintaining the delicate balance between humans and nature.

Tiger conservation- BRT is situated in South-Eastern Karnataka, and is considered a Tiger reserve area. A study by an NGO (Survival International), working towards cause of tribal rights, has reported that the 
population of tigers has increased in recent times. The primary reason for this is that the Soliga tribe worships tigers as Gods, and avoid hunting or conflict at all costs. The Soliga tribe worships animal gods like the elephant (ane devaru), bear (karadi devaru), wild boar (handi devaru), bison (kadamme devaru), and the tiger (huliyirappa devaru) who is considered to be the mount of Lord Mahadeswara, The Soligas are well versed with animal habitats, food habits, reproduction season and other such details. This traditional knowledge of the Soligas helps them in understanding habitats and behavioural patterns of the tigers, and thus avoiding conflict. Their traditional knowledge also serves as the primary link for researchers to understand the forest ecosystem. The invaluable inputs given by the tribal aids in forest management and conservation.

Ironically, it is the tribal community that often takes a hit, as they are asked to leave the lands the traditionally occupied, under the garb of tiger conservation. In the year 2014, hundreds of Baiga tribe were evicted from Kanha Tiger Reserve for the purpose of conservation. However, on the contrary, over a hundred thousand tourists are welcomed into the reserve every year. However, as evident from the example of the BRT Tiger reserve, tigers tend to do well and their population rises when the tribal communities remain. Thousands of tourists who visit these tiger reserves bring in huge amounts of money, and thus serves as a lucrative business. This has grave and far reaching consequences. The constant human presence in these reserves because of the tourists makes the tigers accustomed to human presence, which in turn helps the poachers get close to the tigers.

\section{Indigenous People, Biodiversity \& Law}

During British period, 97\% forest fell under ownership of state. This led to acute problem for indigenous community. In 1988, National Forest Policy, gave some respite to forest dwellers and similar groups by giving them certain rights. The contours of a protected area were decided in the landmark case of Tarun Bharat Sangh v Union of India, wherein the Supreme Court clarified that the term 'protected area' was intended to refer to all areas which have legal protection against non-forest activities that devastated the environment including poaching, mining, felling of trees etc.'

It was in 2003 that the definition of 'Protected area' was inserted. A protected area means 'a national park, sanctuary, conservation reserve or a community reserve as notified under the Act. Further, Chapter IV of the Wildlife Protection Act deals with protected areas. 
One of the biggest breakthroughs in wildlife protection has been the setting up of sanctuaries and national parks.

Any area can be declared as a sanctuary under Section 18 if (i) the area does not comprise of any reserve forest or territorial waster and is of adequate ecological faunal, floral, geo-morphological, natural or zoological significance, (ii) it has been notified so, with clear specification as to the situation and limits of the area, ( iii) a notice has been given to all persons, claiming any right to prefer a written claim before the Collector and applying for compensation, ( iv) the legitimate claims have been settled by the State. If the area to be declared as sanctuary, falls within a reserve

Wildlife Act- Tigers have now been shifted to Schedule I of Wildlife Protection Act giving them protection against hunting and poaching by human. This act was the first comprehensive umbrella legislation for the protection of wildlife. Another noteworthy feature was that the Forty- Second Constitutional Amendment in 1976, shifted and wildlife from state to concurrent list. Now central government held more power towards wild animals in protecting and developing wildlife policy (Rosencranz, A. 2005).

In the month of January, 2011, BRT Wildlife Sanctuary was converted to BRT
Tiger Reserve. This led to danger of the sustenance of 6,000 Soligas and 10,000 acres of forest which acted as buffer zone around the sanctuary. By the end of year, they won the rights to live and means of livelihood through collection of produce of forest which is actually not timber in their ancestral land which was falling under the tiger reserve. The FRA also gave adivasis the "right of ownership, access to collect, use and dispose of minor forest produce, which has been traditionally collected within or outside village boundaries". The FRA has provided with right of habitat and use of jungles for livelihood for such tribes living before December 13, 2005.

Forest Act- Previously, the wildlife was protected. This protection was done for the purpose of hunting the animals as a means of entertainment or gaming. Later the Indian Forest Act came into pictures in 1927. This particular act took specific provisions towards restrictions in hunting and ultimatly safeguarding forest, wild animals and sanctuaries. Scheduled Tribes and Traditional Forest Dwellers (Recognition of Forest Rights) Act, 2006, or Forest Rights Act (FRA) was the subsequent act aimed at guaranteeing certain rights to tribal or adivasi communities.

The Soliga indigenous community with the right to dwell alongside tigers, got the 
facility of understanding the strength of tigers. According to the report, there is a sharp increase in tigers to $100 \%$ capacity (35 in 2010 to 68 in 2014).

\section{Biodiversity Governance and}

\section{Community based Conservation models-}

By September of 2010, National Biodiversity Strategies and Action Plans (NBSAPs) was adopted by 171 countries. This shows the future of biodiversity conservation is bright as the achievement of the three main objectives of the Convention on Biological Diversity (CBD), 1993 is likely:

i. Requirement of conserving biodiversity

ii. The produce of biodiversity to be used in sustainable manner; and

iii. Access and benefit sharing of traditional knowledge and other resources.

According to an estimate, 1.3 billion people are dependent on forests for their livelihoods throughout the world (Manginis, 2005). "Throughout the world there has been a re-examination of who makes decisions about forests and how these decisions are made". Apart from this, the failing ecosystem and biodiversity, in dire ned of restoring, is another issue. It is believed to be conservation which is primarily out of the theory of being community-based "place some power in the hands of rural groups who live close to the resources in question" (Manginis, 2005).

\section{Setting a Precedent}

Villagers in Assam rallying to save Greater Adjutant stork, as well as local initiatives taken to save India's Red Panda are reflective of a similar community based model of conserving the environment. The case most similar to the BRT reserve model is that of the Baiga tribe of Central India. It is surrounded by greenery with small villages encapsulated inside it. Biaga tribe stays symbiotically with the forest, tigers, other wild animals, biodiversity and landscape and preserving them since. From Kanha in Madhya Pradesh to Bhoramdeo Wildlife Sanctuary in Chhattisgarh, Baiga tribes are spread across. The central government has given prominence to them by declaring them vulnerable group. They are concerned about losing their identity with their uprooting.

\section{Soliga Tribe, Tigers \& The Conflict}

Since 1807, historically, the presence of Soliga tribe in Biligiri Rangana Hills can be traced back. According to the estimates for government officials, their population is around 16500 and are established in 61 villages in and around forest. From 1974 onwards, the forest area covering around $540 \mathrm{sq} \mathrm{km}$ comprising of $32 \mathrm{sq} \mathrm{km}$ enclosures and 1800 acres of coffee estates by corporates, Government of Karnataka, 
started proposing its conversion to Biligiri Ranganatha Temple Wildlife Sanctuary (BRT). When the notification finally was posted in 1994, there was no mention of the Soliga tribes living here. They were not considered under any count as per provisions of Section 19 to 26 of the Wildlife (Protection) Act 1972 relating to sanctuary or national Park. From the date of notification, the tribe was asked to evict the area as their activities were considered illegal. Even collecting wild plants and berries, which was a means of their livelihood, was termed illegal. In 2006, the new act, FRA gave them hope. They could be considered as right holders under community forest rights. They started applying for it but around the same time, National Tiger Conservation Authority had approved a proposal by the Karnataka Forest Department to declare BRT a tiger reserve. In this proposal as well Soliga tribes were ignored. In fact, their villages were declared to be "core area" for the purpose of tiger reserve which meant they had to leave village for tiger's sans human area. The common understanding says, a wild animal will only survive in the absence of human interference. This common notion was proved wrong by Soliga tribe. BRT in its independent research has presented a shocking data that after Kaziranga, BRT has presented the tiger population density wise is second highest in the country (11.3 tigers / $100 \mathrm{sq}$ $\mathrm{km})$. Interestingly, they are living in symbiotic relation with the same tribe which were asked to evict so that tigers could thrive peacefully sans human presence.

Another example of the human animal interface and its positive result can be felt in Bhadra Tiger Reserve. When the tribal population comprising of 450 families lived in the vicinity, in 1997, its tiger density was estimated at 3.4 tigers / $100 \mathrm{sq} \mathrm{km}$. For the reserve, the tribes were asked to vacate the land. After more than ten years, in 2013, Bhadra reported 2.3 tigers / $100 \mathrm{sq} \mathrm{km}$, while prey populations showed no increases either.

There are other positive examples like in Gir and Rajaji National Parks. The wildlife habitat showed a recovery path once Maldharis and Gujjar tribes started relocating in the area.

The conflict between tourists and peace and tranquillity of tigers lead to the find a place in quite domain of Kanha, which is predominantly occupied by Baiga tribe in Bhoramdeo Wildlife Sanctuary in Chhattisgarh. The tribal population have complained that government authorities insists on our migration from there to accommodate growing and migrating population of tigers. 
Therefore, one can say that this is not a single blocked out incident for a tribal community as in case of Soliga Tribes. This kind of experience is shared by various other tribes of our country. The trial population of these forest area may learn from the experience of Soliga tribes. One of the primary reasons for the success of this model is that the basic religious belief and practice are in consonance with the ethics and culture towards safeguarding the biodiversity of the area in which they reside. Taking Soliga tribe as an example, they believe that the cutting of trees is a sin and they need to give the status of god to tigers. The co-existence of tribal and animals thus acts as a catalyst in conservation efforts. With the help of rules and regulations in FRA, the tribal population can have a better future with their indigenous roots intact.

\section{CONCLUSION}

The Millennium Ecosystem Assessment (MEA, 2005) have done research on extinction rates of species. It is proved that the human intervention has led to extinction by thousand times more as compared to extinction rates by natural processes (Krishnan, P., et al., 2012). India stands at $17^{\text {th }}$ position among countries, which have been categorised as megadiverse. Forming a part of this megadiverse ecosystem is one of the God's most majestic creation- the tiger. An epitome of beauty, grace and form, and member of the cat family, the tiger is the largest of the four "big cats", lions jaguars, leopards being the others. The tiger is also an apex predator. Three out of the nine subspecies of modern tiger are today extinct. The remaining six are classified as critically endangered. The primary direct causes are habitat destruction, fragmentation and hunting.

The eviction of indigenous people from their homeland is not a step towards biodiversity conservation, but an act that further disturbs the delicate balance between nature and tribal. The traditional knowledge of the Soliga tribe and their presence in the reserve not only strengthens conservation efforts, but also serves as a model for promoting conservation efforts, while empowering the tribal communities.

"It is time we relook at our conservation policies and strategies," says ecologist S. Faizi, the first chairperson of Convention on Biological Diversity Alliance. The value of traditional knowledge was recounted at the 12th meeting of the Conference of the Parties to the Convention on Biological Diversity, held in Korea in October 2014. One of the Millennium Development Goals (MDGs), "that identified poverty eradication and environmental sustainability as global imperatives" was 
adopted to give impetus to communitybased representations. It was felt that it would not be possible to achieve these goals without focusing on the link between environment and poverty and acknowledging the central role of local governance institutions. A model of conservation, such as the one implemented in the BRT Reserve serves a two-fold objective- biodiversity conservation, and tribal empowerment. Displacing and disenfranchising the tribal will not aid in conservation efforts. The tribal are considered to be the natural owner and custodian of biodiversity historically because they have lived their whole life in forests depending on it for their survival. This has given them the tendency to nurture its wildlife for centuries. They will in fact play a pivotal role in biodiversity conservation and sustainable development.

\section{REFERENCE}

[1] Berkes, F. 1977. Fishery resource use in a subarctic Indian community. Hum. Ecol. 5, 289-307.

[2] Berkes, F. 1979. An investigation of Cree Indian domestic fisheries in northern Quebec. Arctic 32, 46-70.

[3] Berkes, F. 1982. Waterfowl management and northern native peoples with reference to Cree hunters of James Bay. Musk-Ox 30, 23-35.
[4] Berkes, F. 1993. Traditional ecological knowledge in perspective. In: Traditional Ecological Knowledge. UNESCO Canada/MAB, Ottawa. (In press)

[5] Beteille, A (1986): 'The Concept of Tribe with Special Reference to India', European Journal o'f Sociology (27). -(1993)

[6] Bachelet, M. 2019 UN High Commissioner for Human Rights, "Comment by UN High Commissioner for Human Rights Michelle Bachelet Jeria on Indonesia (Papua and West Papua)", https://www.ohchr.org/EN/NewsEv ents/Pages/DisplayNews.aspx ?NewsID $=24942 \&$ LangID $=\mathrm{E}$

[7] Biodiversity and Ecosystems Global Framework 2012-2020, The Future We Want: Biodiversity and Ecosystems - Driving Sustainable Development, UNDP.

[8] Collaborative Conservation: Soliga Cultural Ecology and Biodiversity Conservation in Biligiri Rangaswamy Temple Wildlife Sanctuary, India, Annual meeting of the International Congress for Conservation Biology, Convention Center, Chattanooga, TN. July 10, 2008. 
[9] Begossi, A. 2013a. Folk taxonomy: applications in fisheries. In $\mathrm{J}$. Fischer, ed. Fish Identification Tools for Biodiversity and Fisheries Assessments: Review and guidance to managers and other decisionmakers, pp. 70-72 (Annex 3), based on Workshop on "Fish Identification Tools for biodiversity and Fisheries Assessment" convened by FAO and the University of Vigo 11-13 October 2011 in Vigo, Spain, FAO, Rome.

[10] Costa-Pierce, B.A. 1988. Traditional fisheries and dualism in Indonesia. Naga 11, 3-4.

[11] Environmental Law and Policy in India, Cases, Materials and Statutes, Shyam Divan, Armin Rosencranz, 2005, Pg 328

[12] Feit, H.A. 1986. James Bay Cree Indian management and moral consideration of fur- bearers. In: Native People and Renewable Resource Management. Alberta Society of Professional Biologists, Edmonton.

[13] Fischer, J. \& Jorgensen, J. 2013. Fishers' knowledge and the ecosystem approach to fisheries, FAO Fisheries and Aquaculture Technical Paper 591.
[14] Folke, C. and Kautsky, N. 1989. The role of ecosystems for a sustainable development of aquaculture. Ambio 18, 234-243

[15] Folke, C. and Kautsky, N. 1992. Aquaculture with its environment: prospects for sustainability. Ocean Coast. Mgmt 17, 5-24

[16] Gadgil, M. 1987. Diversity: cultural and biological. Trends Ecol. Evolut. 2, 369-373

[17] Gadgil, M. and Guha, R. 1992. This Fissured Land: An Ecological History of India. Oxford University Press, New Delhi, and University of California Press, Berkel

[18] Hardiman, D (1987): The Coming of the Decvi: Adivasi Assertion in Western Itlia, Oxford University Press, Delhi

[19] Irvine, D. 1989. Succession management and resource distribution in an Amazonian rain forest. Adv. Econ. Bot. 7, 223-237

[20] Joshi, N.V. and Gadgil, M. 1991. On the role of refugia in promoting prudent use of biological resources. Theor. Popul. Biol. 40, 211-229.

[21] Krishnan, P., Ramakrishnan, R., Saigal, S., Nagar, S., Faizi, S., 
Panwar, H.S., Singh, S. and Ved, N. (2012). Conservation Across Landscapes: India's Approaches to Biodiversity Governance. United Nations Development Programme, New Delhi, India.

[22] Lewis, H.T. 1989. Ecological and technical knowledge of fire: Aborigines versus park managers in Northern Australia. Am. Anthropol. 91, 940-961.

[23] Leite, M.C.F \& Gasalla, M. 2013. A method for assessing fishers' ecological knowledge as a practical tool for ecosystem-based fisheries management: Seeking consensus in Southeastern Brazil. Fisheries Research, 145: 43-53

[24] M. Jadegowda and M.N Ramesh, Empowerment of Soliga tribes, September 2008.

[25] Madegowda C, Traditional Knowledge and Conservation, Economic and Political Weekly, Vol. 44, No. 21 (May 23 - 29, 2009), pp. 65-69.

[26] Malhotra, K. C. and Poffenberger, M. (ed.). 1989. Forest regeneration through community protection. Proceedings of the Working Group Meeting on Forest Protection Committees, Calcutta,
June 21-22, 1989. West Bengal Forest Department, p. 47.

[27] Malhotra, K.C. 1990. Village supply and safety forest in Mizoram: a traditional practice of protecting ecosystem. p. 439.

[28] Maginnis, Stewart \& Sayer, Jeffrey. (2005). Forests in Landscapes: Ecosystem Approaches to Sustainability. Earthscan

[29] National Wastelands Development Board, Ministry of Environment and Forests, Government of India, 1991. Guidelines for Microplanning. NWDB, N. Delhi, p. 51.

[30] Niamir, M. 1990. Herders' decision-making in natural resources management in arid and semi-arid Africa. Community Forestry Note No. 4. FAO, Rome.

[31] Posey, D.A. 1985. Indigenous management of tropical forest ecosystems: The case of the Kayapo Indians of the Brazilian Amazon. Agrofor. Svst. 3, 139158

[32] Ruddle, K. and Zhong, G. 1988. Integrated Agriculture-Aquaculture in South China. Cambridge University Press, Cambridge, UK.

[33] Sinclair, A.R.E. and Fryxell, J.M. 1985. The Sahel of Africa: Ecology of a disaster. Can. J. Zool. 63, 987-994. 
[34] Slobodkin, L.B. 1968. How to be a predator. Am. Zool. 8, 43-5 1.

[35] Tarun Bharat Sangh, Alwar vs Union of India, 1993 SCC Supl. (3) 115 .

[36] Taylor, K.I. 1988. Deforestation and Indians in the Brazilian Amazonia. In: Biodiversity. Wilson, E. 0. (ed.). National Academy Press, Washington, DC, p. $138-144$

[37] Terborgh, J. 1986. Keystone plant resources in the tropical forest. Conservation Biology- The Science of Scarcity and Diversity. Soule, M. E. (ed.). Sinauer Associates Inc. Sunderland, Massachusetts.

[38] Yan, J. and Yao, H. 1989. Integrated fish culture management in China. In: Ecological Engineering. Mitsch, W. J. and Jorgensen, S. E. (eds). Wiley, N.Y.p. 375

[39] M D Madhusudan, NS Prashanth, Pavithra Sankaran. 2019, Down to Earth. https://www.downtoearth.org.in/bl og/forests/revisiting-the-tigers-vs$\underline{\text { tribals-trope-65782 }}$ 